Volume 5, Issue 3, October 2020, pp. 247-261

DOI: $10.23917 /$ jramathedu.v5i3.10961

p-ISSN: 2503-3697, e-ISSN: 2541-2590

\title{
Designing learning trajectory of circle using the context of Ferris wheel
}

\author{
Nur Lailatul Fitri, Rully Charitas Indra Prahmana* \\ Department of Master Program in Mathematics Education, Universitas Ahmad Dahlan, Yogyakarta, Indonesia \\ *Corresponding author: rully.indra@mpmat.uad.ac.id
}

\section{ARTICLE INFO}

Article history:

Received: 25 May 2020

Revised: 23 June 2020

Accepted: 30 June 2020

Published online: 16 July 2020

Published regularly: October 2020

\section{Keywords:}

Circle, design research, Ferris wheel, Indonesian Realistic Mathematics Education

\begin{abstract}
Ferris wheel is one amusement playground that resembles a giant spinning wheel. Many students are familiar with the Ferris wheel in the mini version of it at night market festivals. This is the potential for learning mathematics. Furthermore, there is a mathematical learning approach called Indonesian Realistic Mathematics Education (IRME) where students learn with contexts which are close to students' life as starting points. Therefore, this study aims to design a learning trajectory using the IRME approach with the Ferris wheel as the context in the learning process to support students' understanding of the learning about circles. The research method is design research that consists of three stages: preliminary design, design experiments, and retrospective analysis. The subjects were 20 eighth-grade students from one of the private Junior High School in Yogyakarta. The instruments used are videos to see the learning process and when students work on the given problems, photos to refer the results of student work, and written test in worksheets to get the data on student's work. The research result explores the learning trajectory practiced using the Ferris wheel as the context seen in the student's daily activities. The learning trajectory consists of four events, namely assembling the Ferris wheel, drawing an illustration of the Ferris wheel, making a list of the circle parts, and solving a problem related to the parts of the circle. Lastly, this study shows that learning trajectory activities have essential roles in supporting students' understanding of the concept of a circle.
\end{abstract}

(C) 2020 Universitas Muhammadiyah Surakarta

\section{Introduction}

Thinking skill is one essential factor of students' success in learning mathematics. It is helpful for students to solve problems (Budiarti, Suparmi, Sarwanto, \& Harjana, 2017; Hwang \& Chen, 2017). Thinking skills can be divided into two parts, namely Low Order Thinking Skills (LOTS) and High Order Thinking Skills (HOTS) (Ahmad et al., 2017; Abdullah et al., 2016). The LOTS consists of three essential cognitive domains of Bloom Taxonomy (remember, understand, and apply) (Tarman \& Kuran, 2015; Kozikoğlu, 2018; Verdina \& Gani, 2018). Furthermore, the HOTS have three most top cognitive domains of

To cite this article:

Fitri, N. L., \& Prahmana, R. C. I. (2020). Designing learning trajectory of circle using the context of Ferris wheel. JRAMathEdu (Journal of Research and Advances in Mathematics Education), 5(3), 247-261. doi: https://doi.org/10.23917/jramathedu.v5i3.10961 
Bloom Taxonomy (analysis, evaluation, and creation) (Tanujaya, Mumu, \& Margono, 2017). However, the existence of these levels does not mean that LOTS is not essential (Erol, Buyuk, \& TanikOnal, 2016; Apino \& Retnawati, 2017). The basic level must be achieved first to move up at the highest level.

Understanding is one of the three basic level capabilities that construct the meaning or concept based on prior knowledge (Lee, Lajoie, Poitras, Nkangu, \& Doleck, 2017; McCarthy \& Goldman, 2019). Furthermore, understanding is learned by integrating new insight into the knowledge already has (Marcelo \& Yot-Domínguez, 2019). Students will understand the concept when they construct the meaning from instructional messages (Russ, 2018). So, understanding is learned by construct definition trough integrated new insight with prior knowledge.

Several studies have been conducted to support students' understanding by designing the learning trajectory using the Indonesian Realistic Mathematics Education (IRME) approach. The approach uses context as a starting point that can help students understand the concept of a circle. Rejeki and Putri (2018) use the IRME approach through tiled settings to help students learning the idea of the area of a circle. In line with this finding, the context of glass in the RME approach also can help students learn the concept of the circle's circumference (Nurdiansyah \& Prahmana, 2017). These researches are several examples of the implementation of the IRME approach at junior high school. Therefore, IRME is considered capable of supporting students' understanding of the concept of the circle at junior high school.

IRME approach is considered capable of support students in understanding mathematical concepts. IRME was adapted from the RME (Realistic Mathematics Education) theory developed by Hans Freudenthal in the Netherlands (Prahmana, Zulkardi, \& Hartono, 2012). This approach can be used to improve students' understanding of mathematical concepts (Laurens, Batlolona, Batlolona, \& Leasa, 2017). IRME approach allows students to discover their mathematical concepts under the teacher (Cobb, Zhao, \& Visnovska, 2008).

The students with strong conceptual knowledge are likely to continue to learn more because their prior experience makes it easier for them to process and use information related to the topic (Booth, 2011). But the fact, most students are difficulty understanding the concept of a circle (Rejeki \& Putri, 2018). Students difficulty determining the center point and the radius of the circle (Akyuz, 2016; Lee \& Yun, 2018). It happens because the learning process emphasizes memorizing formulas rather than understanding the concepts (Indriani \& Julie, 2017; Rejeki \& Putri, 2018). However, the circle becomes essential for learning another geometry topic, such as a sphere.

Alberghi, Resta, and Gaudenzi (2013) have experience in teaching many samples of curves such as parabolas, clothoid, and straight using amusement park as a context. They said an amusement park is a beautiful place where conics become visible and closer to the students' previous experience, so that learning mathematics involves experimenting models on the field, and where amusement and learning do successfully join together. On the other hand, the Ferris wheel is one of the amusement playgrounds that resembles a giant spinning wheel containing mathematical elements used in the circle's learning. Therefore, this study would like to design the learning trajectory of the parts of a circle using the Ferris wheel context for eighth-grade students. This research provides an alternative framework as a starting point for learning circles using daily activities that close to students. 


\section{Research Methods}

The research method used in this study is design research. In design research, an intervention (such as programs, strategies, and materials) for teaching and learning is designed to solve a problem to address in education (Bakker, 2018). It becomes an alternative solution to answer the research question and know about the students learning process. Also, the design research method helps to determine which activities have been designed to support students' understanding of the concept of a circle. This research took place in one of the private Junior High School in Yogyakarta. The participants were eightgrade students which consisted of 12 male students and eight female students. There were three stages in this design research, namely preliminary design, design experiment, and retrospective analysis (Gravemeijer \& Cobb, 2006).

\section{Preliminary design}

The preliminary design phase formulated the learning trajectory elaborated and refined in the experimental design phase (Gravemeijer \& Cobb, 2006). There were three activities in this phase. First is choosing a teacher who teaches in the learning process. Second is preparing the learning activities through a literature review about the concept of the circles using the Ferris wheel and the Indonesian Realistic Mathematics Education (IRME) approach. Lastly is obtaining information about students' difficulties in learning circles and the activities that can support students' understanding of circles concept. This information is used to design the Hypothetical Learning Trajectory (HLT), which consists of three components: a learning goal, a set of the learning task, and a hypothesized learning process (Van den Akker, Gravemeijer, McKenney, \& Nieveen, 2006). The hypothesized learning process, namely conjecture, serves as a guideline that will develop in every learning activity. It also has to be flexible and able to be revised during the design experiment phase. The overview of the activities and the conjecture of students thinking are described in Table 1.

Table 1

The overview of the activities and conjecture of the learning process

\begin{tabular}{|c|c|c|}
\hline Activity & Main goal & Conjecture \\
\hline $\begin{array}{l}\text { Assembling the Ferris } \\
\text { wheel }\end{array}$ & $\begin{array}{l}\text { Figuring out the parts of the } \\
\text { Ferris wheel }\end{array}$ & $\begin{array}{l}\text { - Students collect the information about } \\
\text { the Ferris wheel first and then make it } \\
\text { - Students confuse to rearrange the cabin }\end{array}$ \\
\hline $\begin{array}{l}\text { Drawing an illustration of } \\
\text { the Ferris wheel }\end{array}$ & $\begin{array}{l}\text { Determining the center point } \\
\text { of the circle }\end{array}$ & $\begin{array}{l}\text { - Students draw the circle using or } \\
\text { without equipment } \\
\text { - Students bring the center point directly } \\
\text { - Students draw two intersecting lines } \\
\text { then mark the intersection points } \\
\text { - Students fold the paper into equal parts } \\
\text { and then score the intersection points }\end{array}$ \\
\hline $\begin{array}{l}\text { Making a list the parts of } \\
\text { the circle }\end{array}$ & $\begin{array}{l}\text { Completing the table by } \\
\text { drawing and define the part of } \\
\text { the circle }\end{array}$ & $\begin{array}{l}\text { - Students fill all tables correctly } \\
\text { - Students fill in some of the tables } \\
\text { correctly } \\
\text { - Students cannot fill all tables correctly }\end{array}$ \\
\hline
\end{tabular}


Table 1

Continue

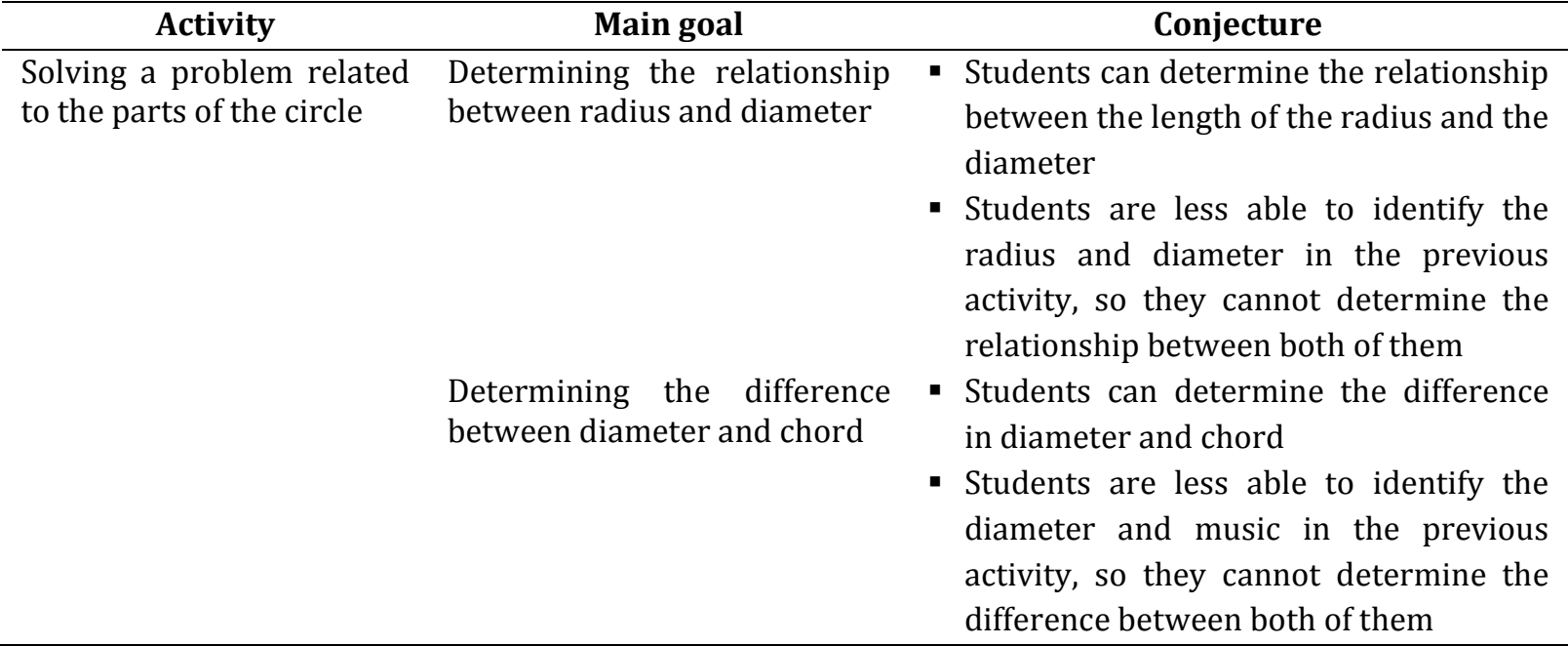

\section{Design experiment}

This phase was divided into two cycles, namely teaching experiment and pilot experiment. In the teaching experiment, the HLT that has been designed in the previous step is implemented in a small group of six students who chosen purposively. The purpose of this phase was to explore and observe the students' strategies and understanding during the learning process. Furthermore, HLT is revised and improved based on the advice of the evaluation in the first phase. The revised HLT in the first cycle was implemented in this second cycle. The second cycle, namely pilot experiment, conducted in the natural classroom setting. The data were collected through classroom observation by video recording and students' worksheets to answer the research questions. Lastly, the group discussion's documentation recorded is to describe the students' understanding during the learning process.

\section{Retrospective analysis}

After conducting a teaching experiment, all the collected data were analyzed in this phase by comparing the conjecture in HLT designed in the first stage with the implementing results of learning trajectory. Furthermore, the role of the learning trajectory became a guide in analyzing the collected data. It allowed to investigate and explain how students understood the concept of the circle. Video recording was the primary data needed to answer research questions. The videos show the students' learning activities and also the students' group discussions. Wijaya (2008) explains that the design research result is not design that works but the underlying principles explaining how and why the design will work. Therefore, the role of HLT has been designed compared to the learning process carried out by students so that an investigation can be carried out and explained how students obtain the concepts of circle generated from the Ferris wheel context.

\section{Results and Discussion}

This research developed a learning trajectory in the parts of the circle through several learning activities for eighth-grade students. The learning activities consisted of four activities, namely assembling a Ferris wheel, drawing a Ferris wheel illustration, making a list of circle elements, and identifying the parts of the circle. 
The teacher started the lesson by asking students about the amusement park. The teacher asked questions to clarify students' knowledge about the Ferris wheel as the context that will be used in the learning process. Students can mention many kinds of amusement ride, as seen in Dialogue 1.

Dialogue 1.

$\begin{array}{ll}\text { Teacher } & : \text { Have you ever visited an amusement park? } \\ \text { Students } & : \text { Yes, I have. } \\ \text { Teacher } & : \text { What are the rides in there? Can you mention them? } \\ \text { Students } & : \text { Kora-kora, kurungan manuk, haunted house, boom boom car, carousel, tong stand. } \\ \text { Teacher } & : \text { How about a Ferris wheel? Have you ever ridden that? } \\ \text { Student } 1 & : \text { Yes, I have. } \\ \text { Student } 2 \quad: \text {. What is a Ferris wheel? }\end{array}$

Based on Dialogue 1, some students did not know about the Ferris wheel. Even though both of kurungan manuk or Ferris wheel are the same thing. The teacher introduces the Ferris wheel context that would be used as a starting point in the learning process. The existence of the student worksheet and exercise material used has a positive impact on stimulating students to think, communicate, and collaborate in the learning process (Yono, Zulkardi, \& Nurjannah, 2019). Furthermore, the teacher shows a video about the Ferris wheel in the Sindu Kusuma Edu Park so that students have the same perception about the Ferris wheel. The student's and teacher's understanding about the context, namely the Ferris wheel used, can facilitate the teaching and learning process more insightful (Alberghi et al., 2013; Stevens \& Moore, 2016). For more details, it can be seen in Dialogue 2 .

Dialogue 2.

Teacher : It is a Ferris wheel at Sindu Kusuma Edupark.

Students : It is kurungan manuk (Ferris wheel in the Javanese language)

Teacher : Both of them are the same. Can you mention the part of the Ferris wheel?

Students : The wheel of a circle, a wheel spoke, kurungan manuk (a cabin).

Dialogue 2 shows that most students are familiar with the term kurungan manuk (Javanese language) compared to the term "Ferris wheel". After watching the video, students know that the Ferris wheel is another name for the kurungan manuk. Furthermore, students understand the parts of the Ferris wheel, such as a wheel, cabins, and a wheel spoke. Therefore, the teacher has an essential role in introducing the context.

Next, the teacher informs about the learning goal that must be achieved by students, which is identifying the parts of the circle. It also tells the students about the learning activities such as group discussions and presentations. The teacher asks students to sit in groups. One group consists of 4 students. They receive worksheets from the teacher that contains several activities.

\section{Assembling a Ferris wheel}

In this informal stage, students are introduced to a circle through a Ferris wheel in an amusement park. Ferris wheel has a giant spinning wheel. Then, they try to assemble a Ferris wheel miniature according to the instructions given on the worksheet. The simulation in this part is one of how to work with mathematical content based on Ferris wheels in the digital culture of a teacher (Júnior, Alves, \& de Moura, 2013). 
Furthermore, there are four student activities to make the miniature of the Ferris wheel. First, cut all components of the Ferris wheel. Second, glue the bottom of the pole using a glue. Third, stick all the gear and cabin to the wheel (clockwise) in the order of color: red, orange, yellow, green, light blue, dark blue, purple, and pink. Lastly, pair the wheel to the pole using a push pin. This miniature has eight cabins with different colors. The position of the cabin can be adjusted by spinning the wheels. Stevens and Moore (2016) show that providing assignments to students who offer opportunities to reason quantitatively can help students' understanding a mathematical concept. In this case, making a Ferris wheel that can dynamically move instead of static encourages students to construct real situations, helping to promote their quantitative reasoning.

The use of something that related or closed to student, such as the Ferris wheel, in the learning process, is one of the characteristics of the IRME approach, namely the use of context. Figure 1 shows students are playing the Ferris wheel by spinning the wheel. It means that the Ferris wheel is a context in this learning activity.

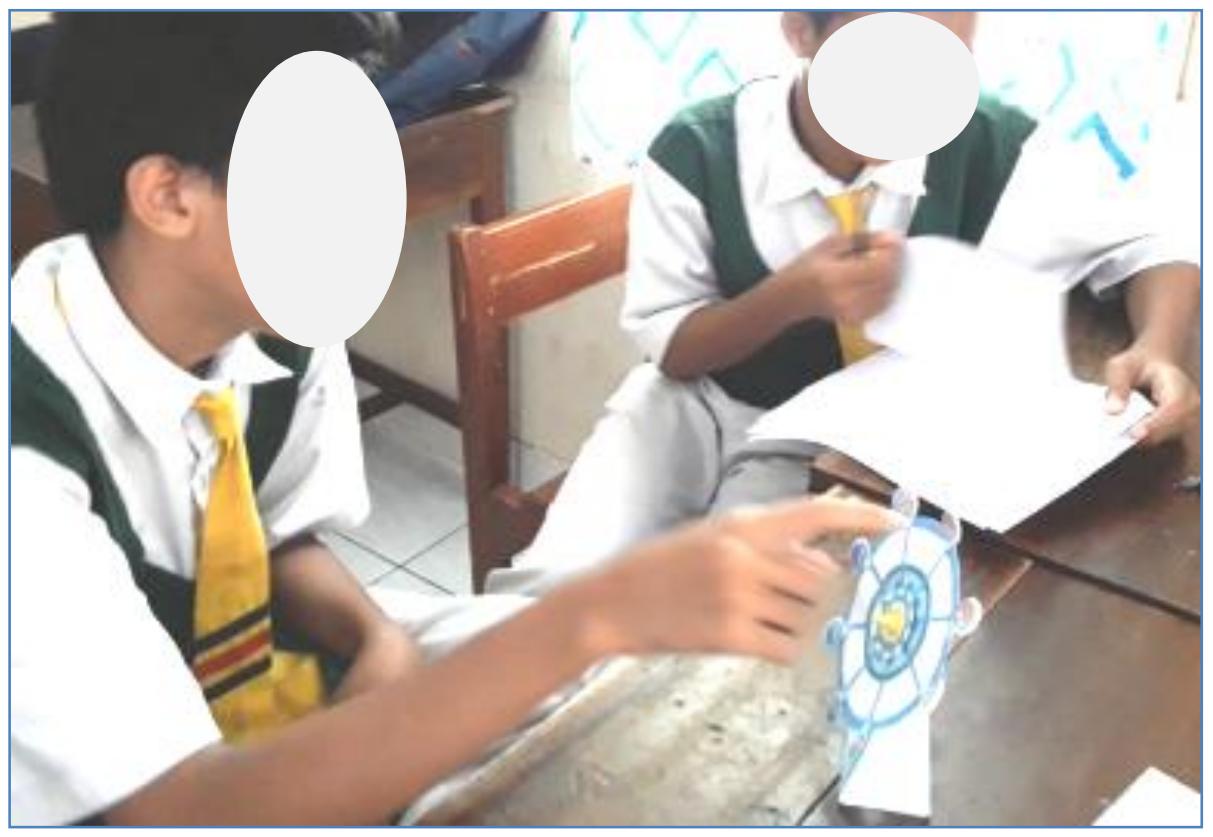

Figure 1. Students spinning the wheel

\section{Drawing an illustration of the Ferris wheel}

In this activity, the teacher asks students to examine the problem on the worksheet. The student worksheet describes that four passengers ride the Ferris wheel with the position, Adil was in the red cabin, Jaya in the orange cabin, Mumpuni in the green booth, and Gayatri in the dark blue cabin. Students are asked to determine the center of the circle. Furthermore, they asked to draw the circle, which illustrated the position of the four passengers with the condition that the red cabin is at the top location. First, students are drawing the circle on the worksheet. The ways of students to draw the circle are different. Group 3 brings a circle immediately without equipment so that their sketch is imperfect.

Meanwhile, another group draws the circle using the equipment. This strategy is in line with the results of the study of Alberghi et al. (2013) which states that most students will not be able to draw a circle without using several supporting equipment. Groups 2 and 5 used the bottle caps to draw the circle. Group 4 drew the circle using the protractor. 
Second, students discuss with their members of the group about the strategy to determine the center point. This activity demonstrated another characteristic of the IRME approach, namely using student contributions. Group 3 determines the center point by drawing the end directly without knowing the correct center point. Group 5 determines the center point by drawing two intersecting lines. Meanwhile, Group 4 determines the center of the circle by using a protractor. This strategy is appropriate with the conjecture of HLT. The groups use a ruler to ensure that the distance of the center point to the side of the circle is equal. However, they realize that their strategy cannot be used because the point is not necessarily located in the center of the circle. So, the teacher gives some clues to them. Furthermore, they found another strategy to determine the center of the circle by folding the paper into several pieces (Figure 2). Then, they draw the points at the intersection of the fold using a pencil.
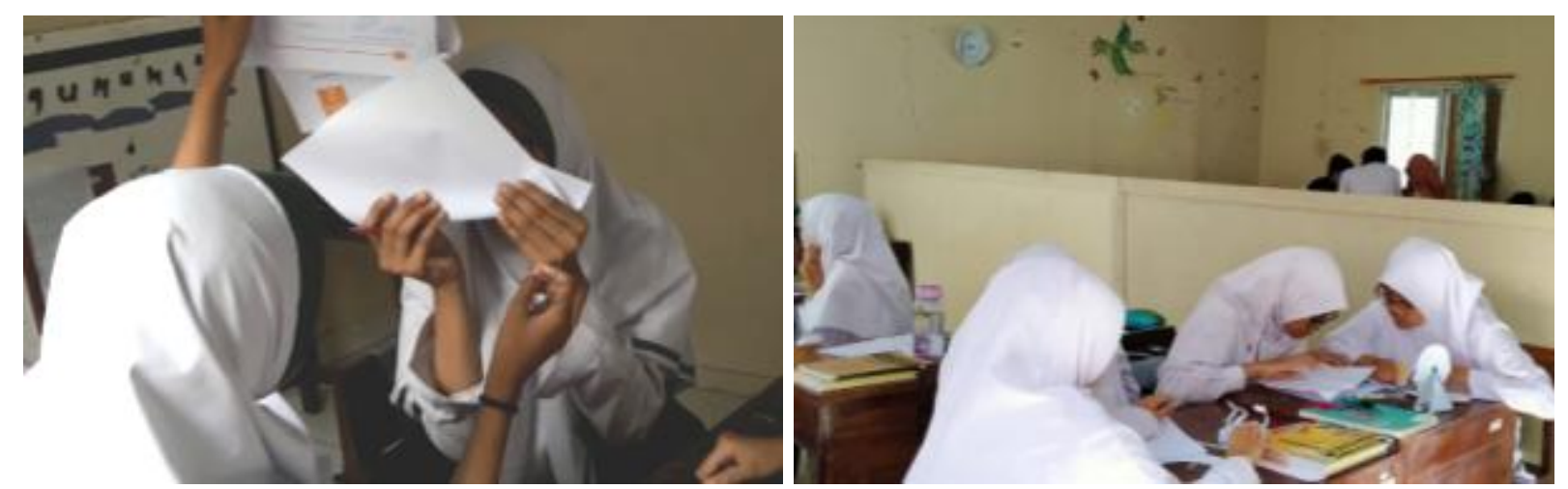

Figure 2. Group 4 and Group 5 folding the paper to determine the center point

Lastly, students spin the wheel so that the red cabin was at the top of the wheel. They drew an illustration of a cabin showing the positions of four passengers, as shown in Figure 3. This illustration will be used in the next activities.

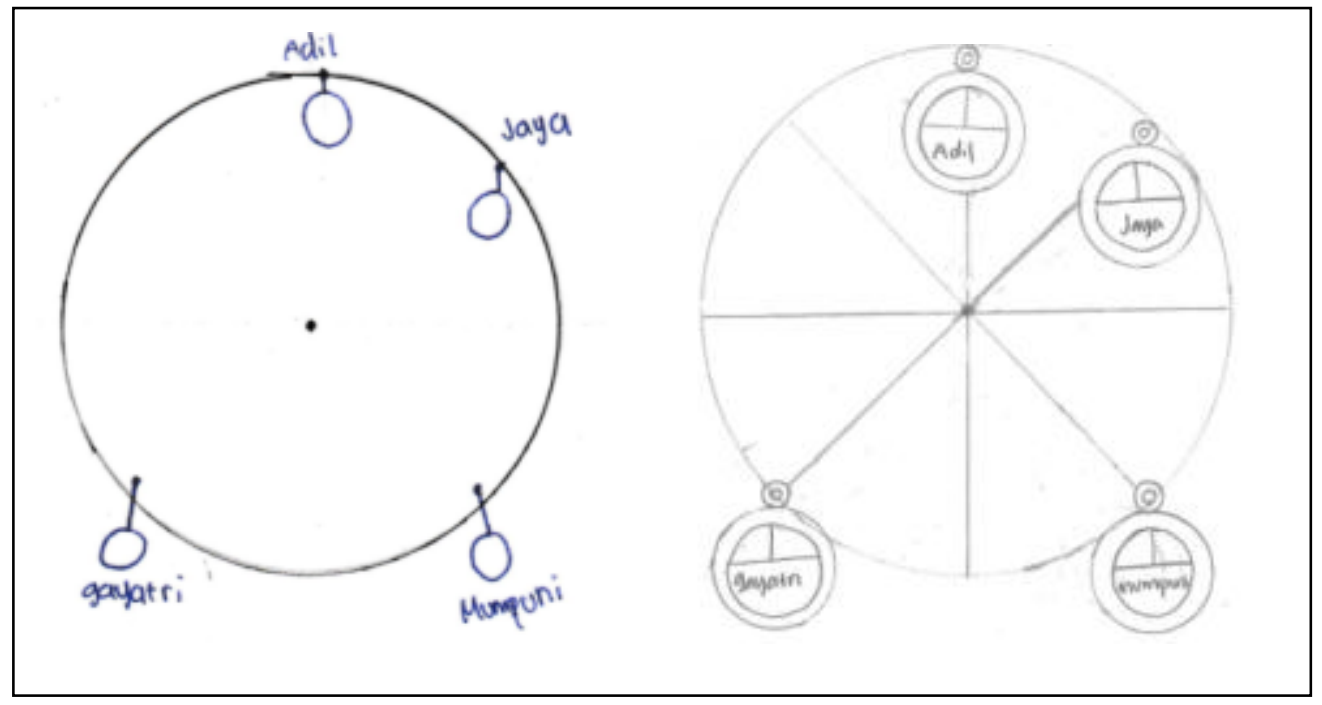

Figure 3. Group 4 and Group 5 draw an illustration of four passenger position 


\section{Making a list of the parts of the circle}

The next activity involved students making a list of the parts of the circle. They completed the table on the worksheet. In this activity, students discussed with their members of their group the strategy to draw the parts of the circle according to the instructions given (model of) and define it (model for). They retained the mathematical concept and recall faster their knowledge by group discussion. This result is supported by Chianson, Kurumeh, and Obida (2010) who explains that cooperative learning that focuses on group discussion can influence students' understanding of a mathematical concept faster.

Group 2 completed all the tables correctly. First, they draw a circle and determine the center point using a folding strategy at the previous activity (intertwinement). Second, they bring a line connecting the center point to Adil cabin (red cabin). Based on their sketch, they describe a radius as a line connecting the center point with another location on the circle. Third, they draw a line connecting the Jaya cabin (orange cabin) and the Gayatri cabin (dark blue cabin). Furthermore, they define diameter as a line connecting two points on a circle and through the center point of the circle (Figure 4).

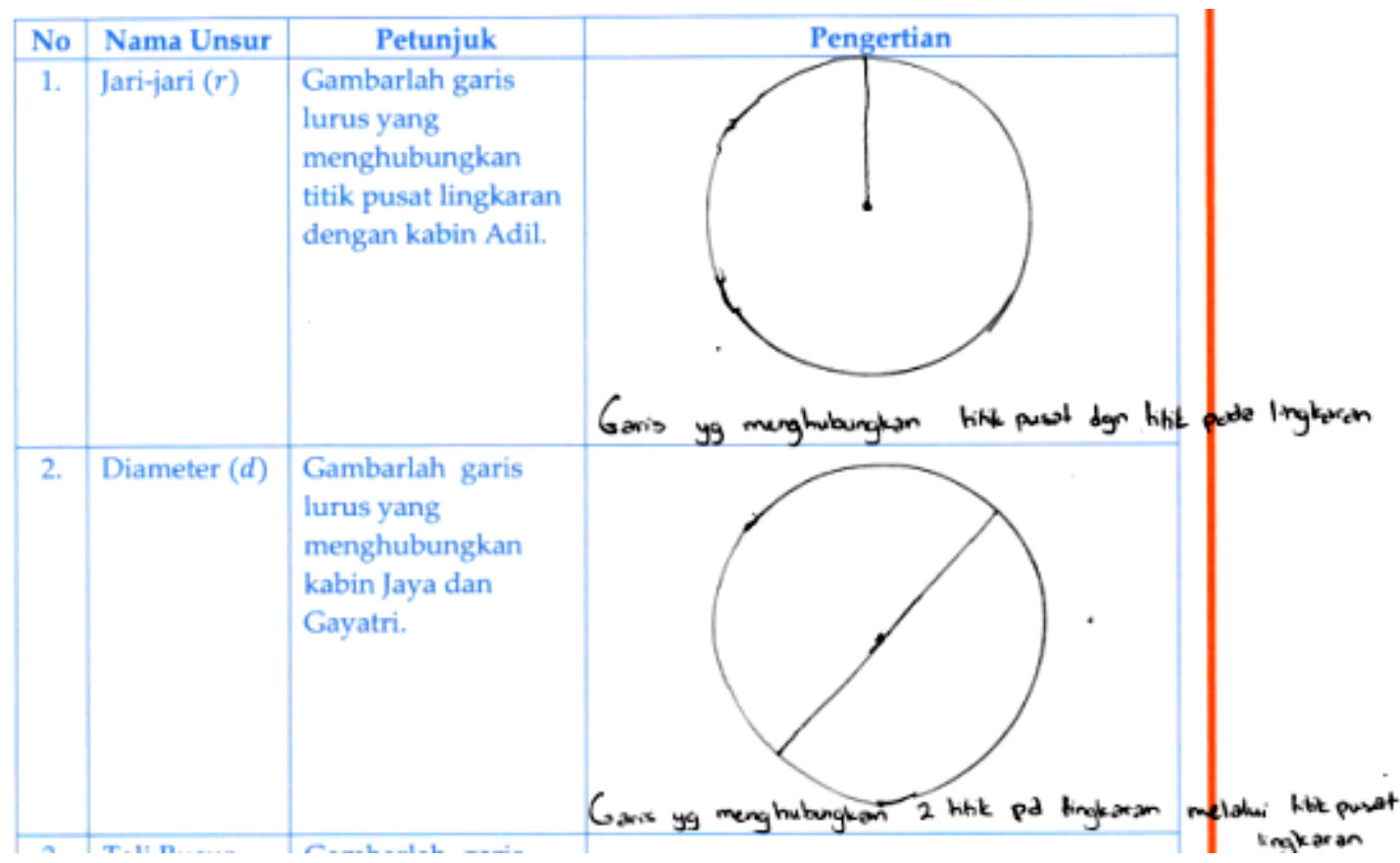

Translation:

\begin{tabular}{|c|l|l|c|}
\hline No & The part names of circle & \multicolumn{1}{c|}{ Instruction } & Definition \\
\hline 1 & Radius (r) & $\begin{array}{l}\text { Draw a straight line } \\
\text { connecting the center of } \\
\text { the circle with the Adil's } \\
\text { cabin }\end{array}$ & $\begin{array}{c}\text { "Figure" } \\
\text { A line connecting the center point with a } \\
\text { point on the circle }\end{array}$ \\
\hline 2 & Diameter (d) & $\begin{array}{l}\text { Draw a straight line } \\
\text { connecting the Jaya's } \\
\text { cabin and Gayatri's cabin }\end{array}$ & $\begin{array}{c}\text { A line connecting two point on the circle } \\
\text { through the center of circle }\end{array}$ \\
\hline
\end{tabular}

Figure 4. The part of the circle table task by group 2 
As shown in Figure 5, Group 2 begins drawing a chord by drawing a straight line connecting the center point with Jaya and Mumpuni's cabin. They should bring a straight line that directly connects Jaya and Mumpuni's cabin.

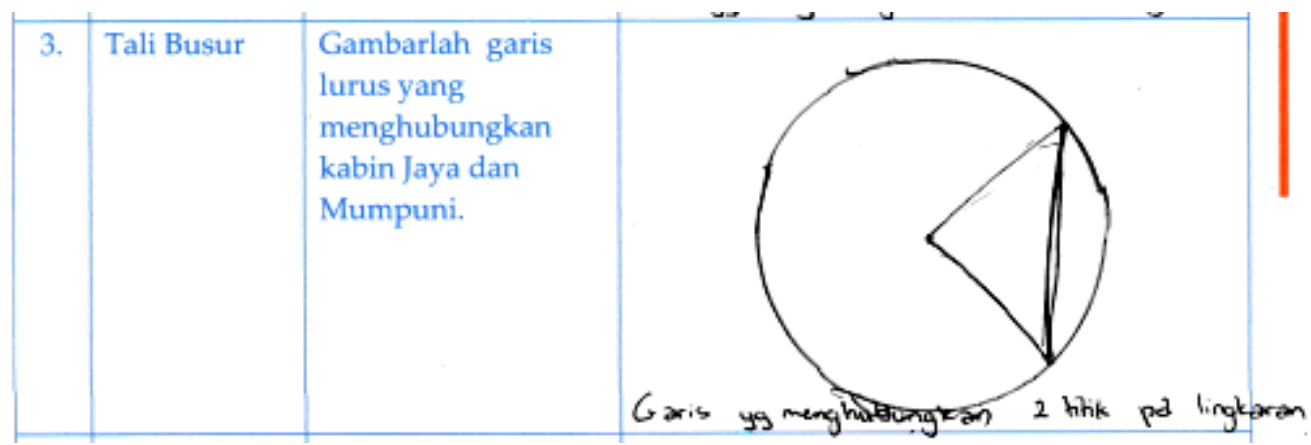

Translation:

\begin{tabular}{|l|l|l|l|}
3 & a chord of a circle & $\begin{array}{l}\text { Draw a straight line connecting the } \\
\text { Jaya's cabin and Mumpuni's cabin }\end{array}$ & $\begin{array}{c}\text { "Figure" } \\
\text { A line connecting two point on the circle }\end{array}$ \\
\hline
\end{tabular}

Figure 5. Group 2 draw an illustration of a chord of a circle

The teacher's role was to guide the students by giving clues. She gives a clue in the form of student worksheets and questions during the discussion process that serves to guide students in finding a part of circle concept. Bruce (2007) said that student interaction is foundational to deep understanding and related student achievement through classroom discussion and other interactive participation. The details of the discussion can be seen in Dialogue 3.

Dialogue 3.

Teacher : Which one is a chord of a circle? Can you show it to me?

Students : It is a chord (*said student while pointing at the picture they've made

Teacher : The instruction on the worksheet is drawing a straight line connecting the Jaya's and Mumpuni's cabins. Can you show me, where is the Jaya's and Mumpuni's cabin?

Students : Right here and here (*student pointing the Jaya's and Mumpuni's cabin).

Teacher : So, which one is a chord of a circle? Can you draw it?

Students : $\quad$ (*students draw a chord base on clues given by the teacher)

After getting some clue from the teacher, they re-drew a chord. They drew a line connecting Jaya's cabin (orange cabin) and Mumpuni's cabin (green cabin). Based on their sketch, they define a chord as a line connecting two points on a circle.

Group 4 understands the instructions thoroughly so they can draw a sector, as seen in Figure 6. First, they bring a line connecting the center point to Adil's cabin (red cabin). Second, they draw a line connecting the center point to Jaya's cabin (orange cabin). Lastly, they shaded the area bounded by both of line. But, they are difficult to define that. Therefore, the teacher's role is needed to help students. 


\begin{tabular}{|l|l|l|}
\hline No & $\begin{array}{c}\text { Nama } \\
\text { Unsur }\end{array}$ & \multicolumn{1}{|c|}{ Petunjuk } \\
\hline 1. & Juring & $\begin{array}{l}\text { Gambarlah garis } \\
\text { lurus yang } \\
\text { menghubungkan: } \\
\text { 1. titik pusat dengan } \\
\text { kabin Adil. } \\
\text { 2. titik pusat dengan } \\
\text { kabin Jaya. } \\
\text { Arsirlah daerah yang } \\
\text { dibatasi oleh kedua } \\
\text { garis tersebut. }\end{array}$ \\
\hline
\end{tabular}

Translation:

\begin{tabular}{|c|l|l|c|}
\hline 1 & Sector of a circle & $\begin{array}{l}\text { Draw a straight line connecting: } \\
\text { 1.the center of circle with the } \\
\text { Adil's cabin } \\
\text { 2. the center of circle with the } \\
\text { Jaya's cabin } \\
\text { Shade the area bounded by these } \\
\text { two lines }\end{array}$ & $\begin{array}{c}\text { "Figure" } \\
\text { arc of circle }\end{array}$ \\
\hline
\end{tabular}

Figure 6. Group 4 complete the part of the circle table

The teacher provided clues to Group 4 (interactivity) so that they could define a sector. This activity provided a deep understanding of students (Bruce, 2007). Next, group 4 represents a sector as the area bounded by two radii and one arc, as seen in Dialogue 4 .

Dialogue 4.

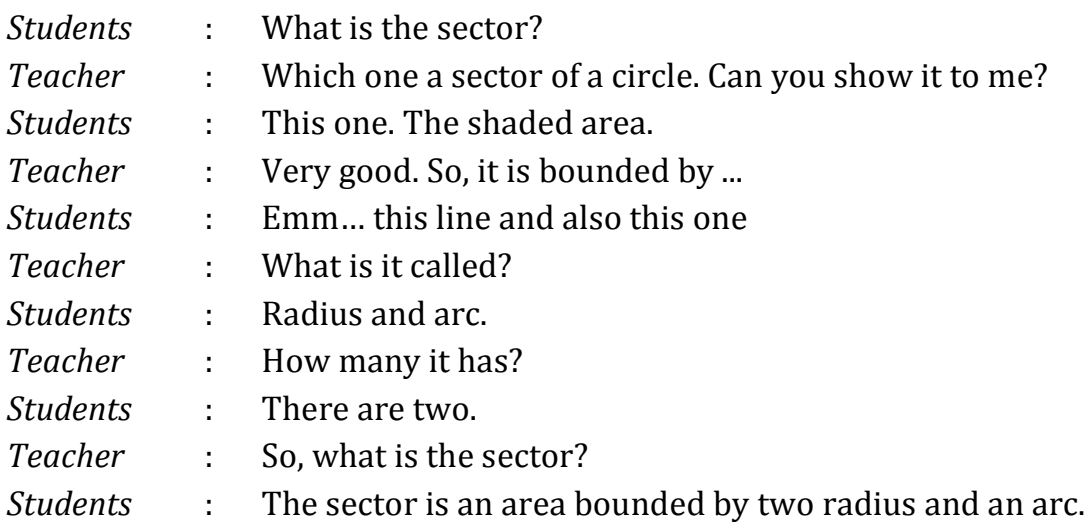

\section{Solving problems related to the parts of the circle}

In this activity, students were asked to solve problems related to the parts of the circle. First, they are asked to determine the length of the diameter by using a given radius. They discuss with their members of the group about the strategy to solve a problem. Based on the previous activity table, Group 2 understands that the length of the radius is half the length of the diameter. As seen in Figure 7, Group 2 multiplied the radius by two to 
determine the length of the diameter. If the length of the radius is $3 \mathrm{~cm}$, then the length of the diameter is $2 \times 3=6 \mathrm{~cm}$.

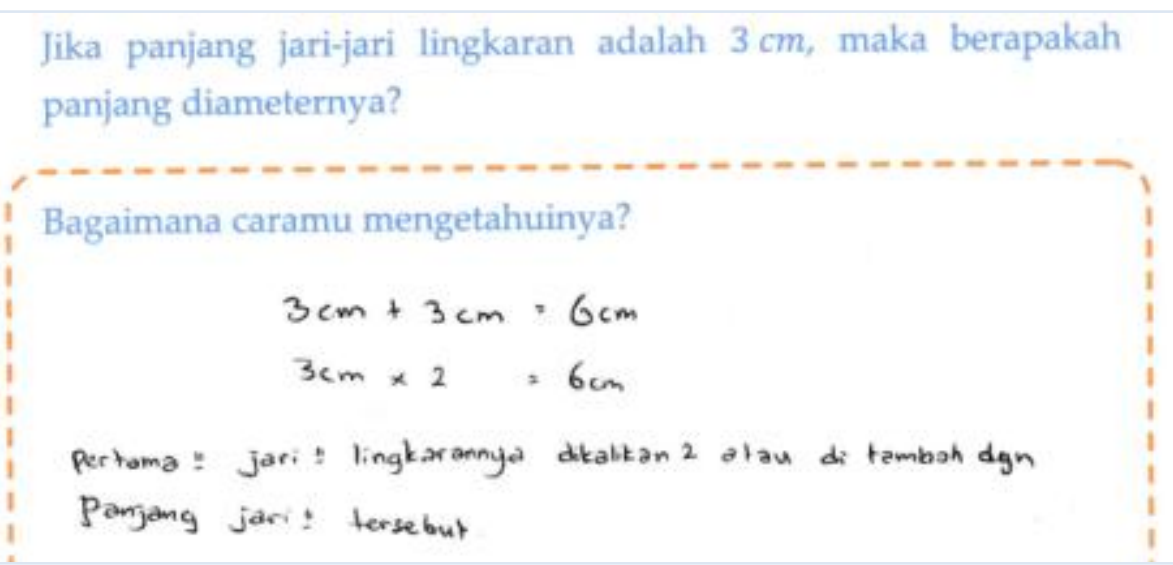

Translation:

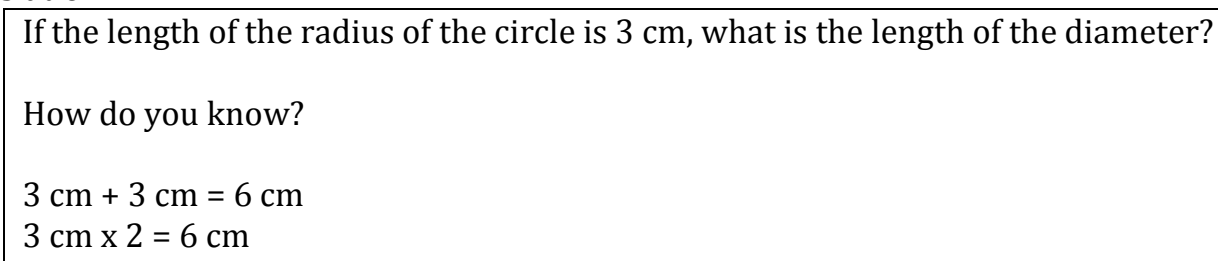

Figure 7. Group 2 explain their answer

Second, students are asked to determine the difference in diameter and chord. Based on table in the previous activity, Group 4 explains that the diameter is a straight line that connects the side of the circle with the other side of the circle by passing through the center point of a circle. In contrast, the chord is a straight line that connects one location to another position and does not cross the center point (see in Figure 8).

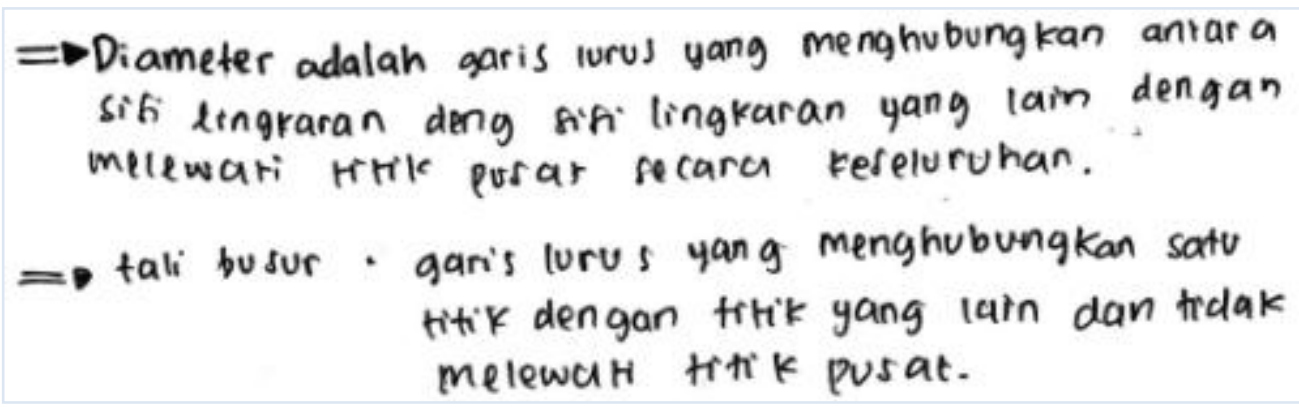

Translation:

The diameter is a straight line connecting between the side of the circle and the other side of the circle through the center of circle as a whole

a chord of a circle $=$ straight line connecting one point to another point and does not cross the center point

Figure 8. Group 4 explain their answer 
Lastly, students can identify the parts of the circle. Figure 9 shows that students can draw the part of the circle, such as center point, radius, diameter, arc, chord, sector, and segment.

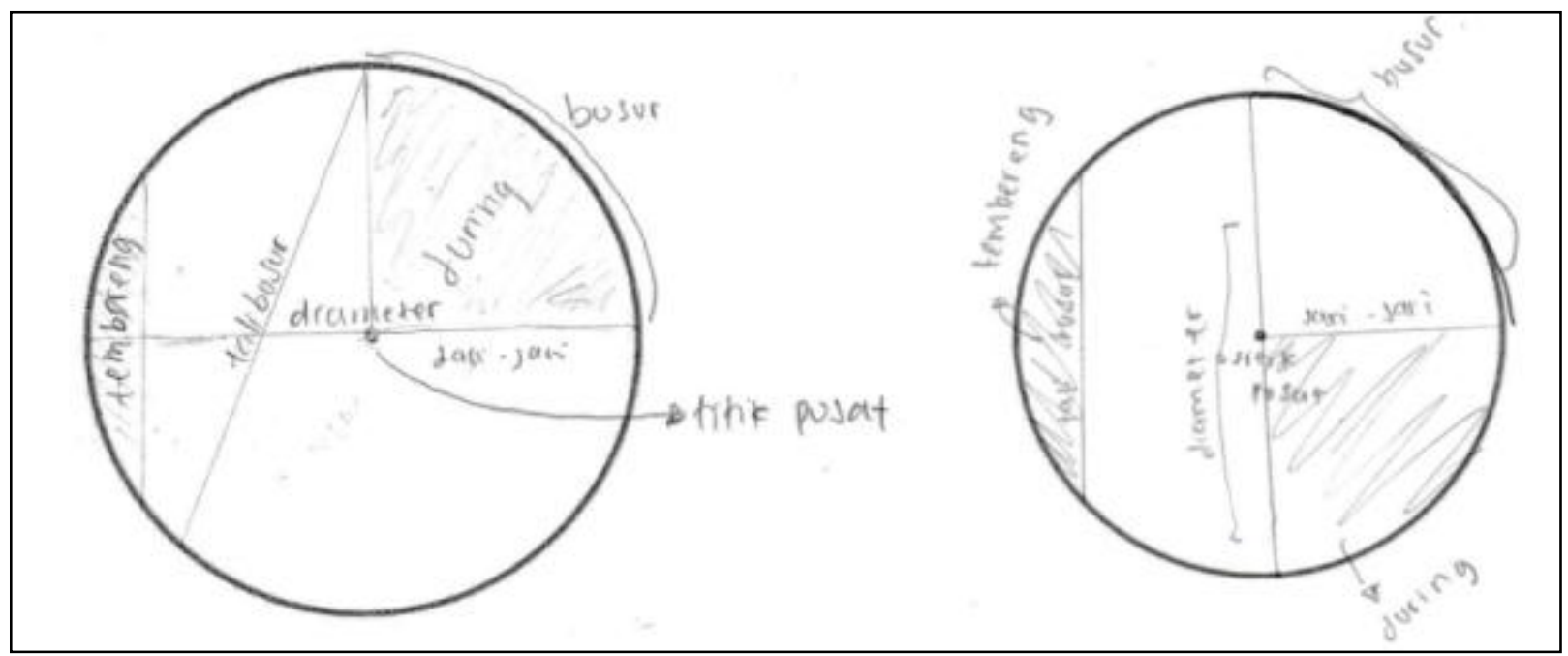

Translation:

$$
\begin{gathered}
\text { Tembereng }=\text { segment } \\
\text { Talibusur }=\text { chord } \\
\text { Diameter }=\text { diameter } \\
\text { Juring }=\text { sector }
\end{gathered}
$$

$$
\begin{gathered}
\text { Jari-jari }=\text { radius } \\
\text { Titikpusat }=\text { center point } \\
\text { Busur }=\text { arc }
\end{gathered}
$$

Figure 9. Students draw the part of the circle

The final designing and developing results of the learning trajectory in this study contributed in the form of several activities to understand the concept of circles for eighthgrade students. These activities explain the steps that must be passed by students using the IRME approach through the context of the Ferris wheel. The steps that must be taken by students are divided into four learning activities, namely assembling a Ferris wheel, drawing a Ferris wheel illustration, making a list of circle elements, and identifying the parts of the circle.

Finally, the results of the evaluation questions given to students showed that, overall, the average score of the students is 3.14 with an Ideal Maximum Score of 4 (good category). It means that students had understood the concepts related to the parts of circle. Therefore, the Ferris wheel has a useful context as a tool used to design a learning trajectory for students' understanding of the concept of the parts of circle. These results supported several previous research results that stated the learning activity related to daily activity could be the starting point in learning mathematics (Alberghi et al., 2013; Cobb et al., 2008; Indriani \& Julie, 2017; Júnior et al., 2013; Laurens et al., 2017; Nurdiansyah \& Prahmana, 2017; Rejeki \& Putri, 2018; Stevens \& Moore, 2016; Wijaya, 2008). Therefore, the learning trajectory using the Ferris wheel can be an alternative activity in learning the concept of a circle for eighth-grade students. 


\section{Conclusion}

The Indonesian Realistic Mathematics Education (IRME) approach using the Ferris wheel context has an essential role in producing a learning trajectory. The learning trajectory can support students' understanding of the concept of the parts of the circle in four activities. Firstly, in the informal stage, they are introduced to a circle through a Ferris wheel in an amusement park. Secondly, students can draw an illustration of four passengers in the Ferris wheel. Thirdly, students are making a list of the parts of the circle. Lastly, students can identify the parts of the circle, determine the relationship between the length of the radius and the diameter, also determine the difference in diameter with a chord. Furthermore, the study's results can be used to implement a learning trajectory that has been designed more broadly. It can also be compared with the results of other activities that use different approaches to generalize the effectiveness of this learning trajectory to improve students' understanding of circles.

\section{Acknowledgment}

Researcher thanks Universitas Ahmad Dahlan for giving the opportunity and facilities so researchers can complete this research. The authors also provide gratitude to SMP IT Al Khairaat and the teacher, who was facilitating researchers with their students as the research subject.

\section{Bibliography}

Abdullah, A. H., Mokhtar, M., Abd Halim, N. D., Ali, D. F., Tahir, L. M., \& Kohar, U. H. A. (2016). Mathematics teachers' level of knowledge and practice on the implementation of higher-order thinking skills (HOTS). Eurasia Journal of Mathematics, Science and Technology Education, 13(1), 3-17. https://doi.org/10.12973/eurasia.2017.00601a

Ahmad, S., Prahmana, R. C. I., Kenedi, A. K., Helsa, Y., Arianil, Y., \& Zainil, M. (2018). The instruments of higher order thinking skills. Journal of Physics: Conference Series, 943(1), 012053. https://doi.org/10.1088/1742-6596/943/1/012053

Alberghi, S., Resta, L., \& Gaudenzi, S. (2013). Experiencing mathematical modelling in an amusement park. Journal of Mathematical Modelling and Application, 1(8), 3-17.

Apino, E., \& Retnawati, H. (2017). Developing instructional design to improve mathematical higher order thinking skills of students. Journal of Physics: Conference Series, 812(1), 012100. https://doi.org/10.1088/1742-6596/812/1/012100

Akyuz, D. (2016). Mathematical practices in a technological setting: A design research experiment for teaching circle properties. International Journal of Science and Mathematics Education, 14(3), 549-573.https://doi.org/10.1007/s10763-014-9588-z

Bakker, A. (2018). Design Research in Education. London: Routledge.

Booth, J. L. (2011). Why can't students get the concept of math. Perspective on Language and Literacy, 37(2), 31-35.

Bruce, C. D. (2007). Student interaction in the math classroom stealing ideas or building understanding. What Works, 1-4. Retrieved from http://www.edu.gov.on.ca/eng/literacynumeracy/inspire/research/bruce.pdf

Budiarti, I. S., Suparmi, A., Sarwanto, \& Harjana. (2017). Analyzes of students' higher order thinking skills of heat and temperature concept. Journal of Physics: Conference Series, 909(1), 012055. https://doi.org/10.1088/1742-6596/909/1/012055

Chianson, M. M., Kurumeh, M. S., \& Obida, J. A. (2010). Effect of cooperative learning 
strategy on students' retention in circle geometry in secondary schools in Benue State, Nigeria. American Journal of Scientific and Industrial Research, 2(1), 33-36. http://dx.doi.org/10.5251/ajsir.2011.2.1.33.36

Cobb, P., Zhao, Q., \& Visnovska, J. (2008). Learning from and adapting the theory of realistic mathematics education. Éducation Et Didactique, 2(1), 105-124. https://doi.org/10.4000/educationdidactique.276

Erol, M., Buyuk, U., \& TanikOnal, N. (2016). Rural Turkish students' reactions to learning science in a mobile laboratory. Educational Sciences: Theory and Practice, 16(1), 261277. https://doi.org/10.12738/estp.2016.1.0171

Gravemeijer, K., \& Cobb, P. (2006). Design research from a learning design perspective. In Jvd. Akker, K. Gravemeijer, S. Mckenney, \& N. Nieveen (Eds.), Educational Design Research (pp. 17-51). London: Routledge.

Hwang, G. J., \& Chen, C. H. (2017). Influences of an inquiry-based ubiquitous gaming design on students' learning achievements, motivation, behavioral patterns, and tendency towards critical thinking and problem solving. British Journal of Educational Technology, 48(4), 950-971. https://doi.org/10.1111/bjet.12464

Indriani, N., \& Julie, H. (2017). Developing learning trajectory on the circumference of a cycle with Realistic Mathematics Education (RME). AIP Conference Proceedings, 1868(1), 1-9. https://doi.org/10.1063/1.4995149

Júnior, A. J. de S., Alves, D. B., \& de Moura, É. M. (2013). Mathematics Education in a Digital Culture. Journal of Mathematical Modelling and Application, 1(8), 32-41.

Kozikoğlu, İ. (2018). The examination of alignment between national assessment and English curriculum objectives using revised Bloom's Taxonomy. Educational Research Quarterly, 41(4), 50-77.

Laurens, T., Batlolona, F. A., Batlolona, J. R., \& Leasa, M. (2017). How does realistic mathematics education (RME) improve students' mathematics cognitive achievement?.Eurasia Journal of Mathematics, Science and Technology Education, 14(2), 569-578.https://doi.org/10.12973/ejmste/76959

Lee, B., \& Yun, Y. S. (2018). How do college students clarify five sample spaces for Bertrand's chord problem?. EURASIA Journal of Mathematics, Science and Technology Education, 14(6), 2067-2079. https://doi.org/10.29333/ejmste/86163

Lee, L., Lajoie, S. P., Poitras, E. G., Nkangu, M., \& Doleck, T. (2017). Co-regulation and knowledge construction in an online synchronous problem based learning setting. Education and Information Technologies, 22(4), 1623-1650. https://doi.org/10.1007/s10639-016-9509-6

Marcelo, C., \& Yot-Domínguez, C. (2019). From chalk to keyboard in higher education classrooms: changes and coherence when integrating technological knowledge into pedagogical content knowledge. Journal of Further and Higher Education, 43(7), 975988. https://doi.org/10.1080/0309877X.2018.1429584

McCarthy, K. S., \& Goldman, S. R. (2019). Constructing interpretive inferences about literary text: The role of domain-specific knowledge. Learning and Instruction, 60, 245-251. https://doi.org/10.1016/j.learninstruc.2017.12.004

Nurdiansyah \& Prahmana, R. C. I. (2017). Pembelajaran keliling lingkaran menggunakan konteks gelas [Learning circumference of a circle using the context of glass]. Jurnal Riset Pendidikan Matematika, 4(2), 128-140. https://doi.org/10.21831/jrpm.v4i2.14829

Prahmana, R. C. I., Zulkardi, \& Hartono, Y. (2012). Learning Multiplication Using Indonesian Traditional Game in Third Grade. Journal on Mathematics Education, 3(2), 115-132. https://doi.org/10.22342/jme.3.2.1931.115-132 
Rejeki, S., \& Putri, R. I. I. (2018). Models to support students' understanding of measuring area of circles. Journal of Physics: Conference Series, 948(1), 012058. https://doi.org/10.1088/1742-6596/948/1/012058

Russ, R. S. (2018). Characterizing teacher attention to student thinking: A role for epistemological messages. Journal of Research in Science Teaching, 55(1), 94-120. https://doi.org/10.1002/tea.21414

Stevens, I. E., \& Moore, K. C. (2016). The Ferris wheel and justifications of curvature. Proceedings of the 38th annual meeting of the North American Chapter of the International Group for the Psychology of Mathematics Education, 644-651. Tucson, AZ: The University of Arizona.

Tanujaya, B., Mumu, J., \& Margono, G. (2017). The relationship between higher order thinking skills and academic performance of student in mathematics instruction. International Education Studies, 10(11), 78-85. https://doi.org/10.5539/ies.v10n11p78

Tarman, B., \& Kuran, B. (2015). Examination of the cognitive level of questions in social studies textbooks and the views of teachers based on Bloom taxonomy*. Educational Sciences: Theory \& Practice, 15(1), 213-222. https://doi.org/10.12738/estp.2015.1.2625

Van den Akker, J., Gravemeijer, K., McKenney, S., \& Nieveen, N. (2006). Educational Design Research. London: Routledge.

Verdina, R., \& Gani, A. (2018). Improving students' higher order thinking skills in thermochemistry concept using worksheets based on 2013 curriculum. Journal of Physics: Conference Series, 1088(1), 012105. https://doi.org/10.1088/1742$6596 / 1088 / 1 / 012105$

Wijaya, A. (2008). Design research in mathematics education: Indonesian traditional games as means to support second graders' learning of linear measurement. Thesis Utrecht University. Utrecht: Utrecht University.

Yono, S., Zulkardi, \& Nurjannah. (2019). $8^{\text {th }}$ grade student's collaboration in circle material by using system lesson study for learning community. Journal of Physics: Conference Series, 1315(1), 012012. https://doi.org/10.1088/1742-6596/1315/1/012012 